\title{
Report to Congress on the Structural Assessment of the New U.S. Embassy Office Building in Moscow
}

Center for Building Technology National Engineering Laboratory National Bureau of Standards Gaithersburg, MD 20899

April 15, 1987

\section{FILE COPY DO NOT REMOVE}

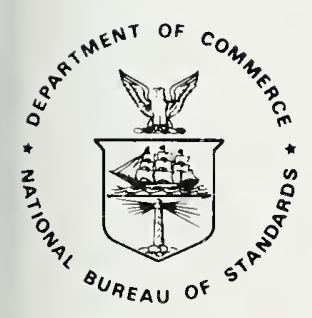

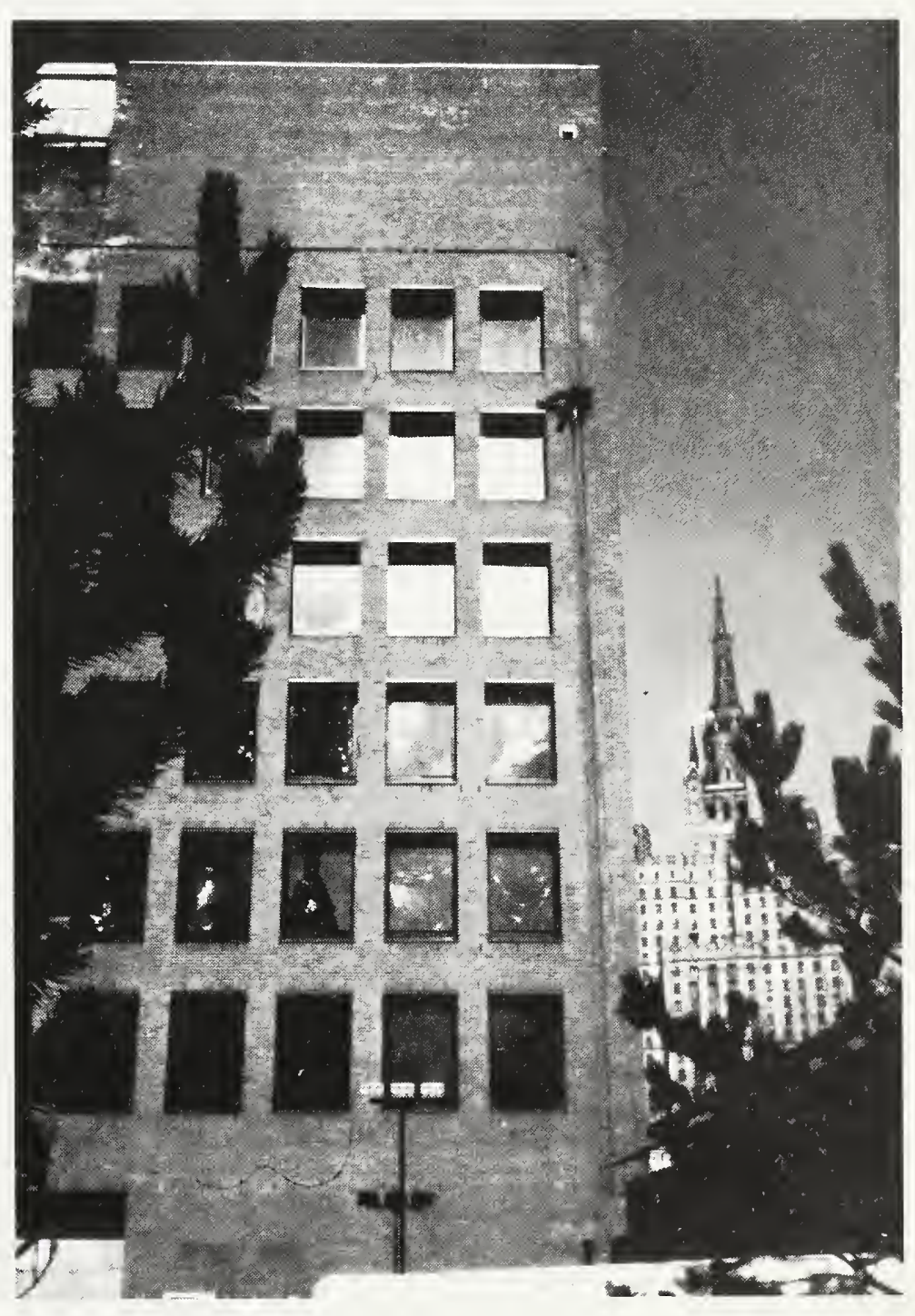

\section{U.S. DEPARTMENT OF COMMERCE} NATIONAL BUREAU OF STANDARDS 
COVER PHOTOGRAPH: NBS Engineer Inspecting the South Elevation, East Corner, of the New U.S. Embassy Office Building 
NBSIR 87-3636

\section{Report to Congress on the Structural Assessment of the New U.S. Embassy Office Building in Moscow}

Center for Building Technology

National Engineering Laboratory

National Bureau of Standards

Gaithersburg, MD 20899

April 15, 1987

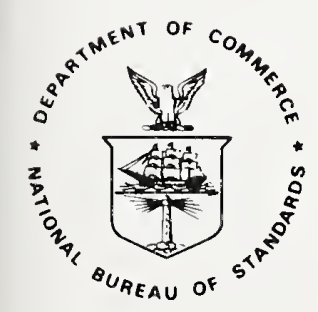

U.S. DEPARTMENT OF COMMERCE, Malcolm Baldrige, Secretary NATIONAL BUREAU OF STANDARDS, Emest Ambler, Director 


\title{
REPORT TO CONGRESS \\ ON THE \\ STRUCTURAL ASSESSMENT \\ OF THE \\ NEW U.S. EMBASSY OFFICE BUILDING IN MOSCOW \\ Center for Building Technology \\ National Engineering Laboratory \\ National Bureau of Standards
}

\begin{abstract}
Public Law 99-591, The Continuing Appropriations Act for Fiscal Year 1987, directed the National Bureau of Standards (NBS) to conduct an independent analysis of the new United States Embassy Office Building being constructed in Moscow. The analysis was to include ". . . an assessment of the current structure and recommendations and cost estimates for correcting any structural flaws and construction defects .... " This report summarizes the investigation, which included field, laboratory and analytical studies, and its findings. The investigation did not address security and other nonstructural deficiencies. The investigation has identified important structural defects in the building and defined remedial measures to correct them. While important, these structural defects, in comparison to the total structural system for the building, are modest in scale and fully correctable.
\end{abstract}

Keywords: Building; concrete; Embassy; construction; investigation; masonry; Moscow; steel; structure 



\section{EXECUTIVE SUMMARY}

Public Law 99-591, The Continuing Appropriations Act for Fiscal Year 1987, directed the National Bureau of Standards (NBS) to conduct an independent analysis of the new United States Embassy Office Building being constructed in Moscow. The analysis was to include " . . an assessment of the current structure and recommendations and cost estimates for correcting any structural flaws and construction defects ... . " This report is submitted in response to the assignment, and summarizes the detailed technical report which has been prepared on the investigation.

NBS has analyzed the structural system of the Office Building and developed recommendations and cost estimates for correcting structural flaws and defects. The scope of the investigation was limited to the structural system, and was not concerned with defects that are neither structural nor threatening to the structural integrity of the building. Activities included review of the documentation for the design and construction of the site and building, formulation of criteria for the assessment to provide a level of safety consistent with good U.S. practice for important office buildings, analysis of the structure as designed for compliance with the criteria, field and laboratory investigations of the as-built characteristics of the structure, analysis of the as-built structure, and development of required remedial measures.

Structural materials and components used in the Office Building are generally of good quality. However, important deficiencies exist in the structure that must be corrected for adequate safety before the building is occupied. These include:

o Inspecting all of the joints between reinforced concrete columns and filling those found to be incomplete.

o Bracing four steel-core columns to provide adequate resistance to buckling.

o Inspecting and completing all joints between shear wall panels and adjacent panels or columns to provide adequate strength and stiffness for resistance to lateral forces.

o Attaching a system of steel straps to the top flanges of eighth floor beams to protect against progressive collapse of the floor system.

o Attaching the floor topping to beams along portions of the east and west exterior walls in stories 2 through 7 to protect against progressive collapse of the floor system.

o Filling gaps between masonry partitions in the core area and surrounding beams and columns, and strengthening the partitions to provide an alternate load path in the event of a column failure.

o Removing and replacing cracked portions of parapet walls, and anchoring the parapet walls adequately to the structure below.

The total estimated cost based on Washington, D.C., prices for conducting these remedial structural measures is $\$ 1,123,000$. 
In addition, the following remedial measures are recommended for the serviceability and durability of the Office Building structure:

o Removing and replacing cracked portions of the penthouse walls.

o Providing vertical expansion joints in the corner piers of the exterior walls.

o Appropriately placing insulation in the corner piers and in cavities above windows.

o Carrying out a program to monitor the development of cracks present in the exterior walls, and to define remedial measures if needed.

The total estimated cost based on Washington, D.C., prices for conducting these additional remedial structural measures is $\$ 341,000$.

Actual costs of the remedial structural measures will depend upon working conditions in Moscow and the means selected for performing the work. These costs do not include the costs of correcting nonstructural deficiencies in the Office Building. These costs do not include the costs for addressing security concerns for the Office Building.

The remedial structural measures do not involve major reconstruction and could be completed in less than a year were the Office Building in the United States. 


\section{INTRODUCTION}

\subsection{Background}

Public Law 99-591, The Continuing Appropriations Act for Fiscal Year 1987, directed the National Bureau of Standards (NBS) to conduct an independent analysis of the new United States Embassy Office Building being constructed in Moscow. The analysis was to include " . . a an assessment of the current structure and recommendations and cost estimates for correcting any structural flaws and construction defect . . . " This report is submitted in response to the assignment, and summarizes the detailed technical report which has been prepared on the investigation [1].

Background information on the new United States Embassy Office Building in Moscow, hereafter called the Office Building, was provided by the Office of Foreign Buildings Operations (FBO) of the Department of State. The Office Building is located in the new Embassy complex on Konyushkovskaya Boulevard one city block west of the present Embassy office building on Chaykovskogo Street. Figure 1 is an architectural rendering of the site and Office Building. The new site was transferred to the United States under the terms of an 85-year lease as defined in the Embassy Sites Agreement between the United States and the Soviet Union signed on May 16, 1969. An agreement on December 4, 1972, established the conditions of construction for the Office Building.

The Office Building was designed from 1973 to 1976 by a combined partnership of two United States firms: Skidmore, Owings and Merrill of San Francisco and Gruzen and Partners of New York. This design established the form, appearance, loadings, structural system, and materials for the structure. The construction contract was signed on June 30, 1979, with the Soviet General Contractor, Sojuzvneshstrojimport. The Soviets were responsible for the detailed structural design and construction using a Soviet building system widely used in Moscow. Construction activities at the site began in 1979. The structural framing was in place in June 1982, as shown in figure 2. The exterior walls were substantially complete in November 1983 when installation of the facing brick was finished. Construction work has been suspended since August 1985 except for placement of a temporary roof in November 1986. A temporary heating system is operating for the Office Building.

\subsection{Scope and Organization of the Report}

The scope of the investigation was limited to the structural system of the Office Building. The investigation did not consider security or other systems of the Office Building, such as heating or plumbing, nor other buildings at the new Embassy site. Also, the investigation did not consider construction defects that are neither structural nor threatening to structural integrity. For instance, incomplete and defective concrete vault walls on the eighth floor of the Office Building have concerned many official visitors. However, these vault walls do not have a structural function, nor do their deficiences handicap the performance or durability of the structure; therefore, they are not considered further. In contrast, deficiences in the facade masonry can be hazardous (if bricks should fall) or threaten durability (entrance of moisture can cause corrosion of structural members); these types of defects are considered. In addition, nonstructural masonry partitions are assessed for their potential to provide alternate load paths in the event of failure of individual structural members.

Metric units are used in this report for consistency with the units used in the original plans, specifications and design documentation. Customary U.S. units are shown in parentheses. 

Section 2, SITE AND BUILDING DESCRIPTION, describes the Office Building site and structural system as designed.

Section 3, LOADING AND RESISTANCE CRITERIA, reviews the loading and resistance criteria for the Office Building and defines the criteria for the assessment.

Section 4, ASSESSMENT OF DESIGN, assesses the design of the Office Building in light of the criteria defined in Section 3.

Section 5, SITE AND LABORATORY INVESTIGATIONS, describes the site investigations and laboratory studies conducted to determine the as-built condition of the structural system. Field and laboratory data are summarized.

Section 6, ASSESSMENT OF THE EXISTING STRUCTURE AND RECOMMENDATIONS FOR REMEDIAL MEASURES, provides the assessment of the as-built structural system and recommendations for remedial measures needed to provide safety, serviceability and durability consistent with good U.S. practice for office buildings.

\subsection{Basis for Assessment of Structural Integrity}

The structural integrity of the Office Building was assessed in terms of good U.S. practice for office buildings. Loadings used for review were consistent with U.S. design requirements for an important public building and the siting of the office building in Moscow. Resistances of structural materials and components to these loadings were evaluated in light of experiences with U.S. practices, knowledge of Soviet materials and components, and laboratory tests and field measurements. Remedial measures are recommended where structural components are overloaded in comparison to good practice for U.S. office buildings. The goal of the recommended remedial measures is for occupants of the Office Building to be as safe from structural hazards as they would be in a well designed and constructed office building in the United States.

In addition to recommending remedial measures for instances in which the level of structural safety falls below the minimum for good practice in the United States, remedial measures also are recommended to correct other structural defects or flaws that are inconsistent with good U.S. building practices. (For good U.S. practice it is neither expected nor required that a structure be completely free of structural defects or flaws, but that they be few in number and inconsequential for structural safety, serviceability or durability.) Action on these additional remedial measures should substantially improve the structure and meet requirements for a sound structural system.

\section{SITE AND BUILDING DESCRIPTION}

The structural system is made up of Soviet-manufactured, precast concrete and structural steel elements erected and fastened together at the site. For this type of construction, the quality of the connections is as important to the structural integrity of the system as the quality of the elements.

The Office Building, as shown in a recent photograph in figure 3, is nearly complete structurally. The structural system is described in this section as it was designed. The structural system includes the foundations; the vertical load supporting system of floors, beams, and columns; the shear wall system providing resistance to lateral forces such as wind; the masonry exterior wall system; and finally, the interior masonry walls, which, although not designed for structural loadings, may be of structural value under extraordinary circumstances. The descriptions in this section are based on project documentation provided by the Department of State. All structural elements and materials, with the exception of the exterior facing brick, are of Soviet manufacture. Results of site 
investigations conducted by NBS to verify these data and to define actual as-built properties are described in Section 5.

The building is $\mathbf{4 1}$ meters (134 feet) square in plan and eight stories tall plus a basement and penthouse. The height from the first floor to the penthouse roof is 37.5 meters (123 feet).

Columns are located at the exterior walls and in the central core area as shown in figure 4. Figure 5 shows a schematic elevation view of the exterior column line on the east side of the building.

According to geological studies conducted for FBO by Soviet organizations, the building site is underlain by rock formations topped by a weathered limestone. The design drawings show that the Office Building is built on pile caps supported by 1092 precast concrete piles, ranging in length from 2 to 11 meters ( 6 to 36 feet), and driven to bearing on the underlying rock. Each of the exterior columns shown in figure 4 is supported by a group of 12 to 20 piles. Large groups of 192 piles each support the east and west halves of the core area at the center of figure 4.

Figure 6 gives a schematic view of a typical portion of the structural system. The floors contain precast concrete planks. Some cast-in-place concrete floor slabs are used in more heavily loaded floor areas, and are used on top of floor planks throughout the eighth floor, except in the core area. The floor planks and slabs are supported on steel or reinforced concrete beams located, typically, as shown in figure 7. Concrete was placed in the joints between planks, and concrete topping containing wire mesh was cast on top of floor planks or slabs. Concrete beams typically are supported by brackets cast integrally with the concrete columns. Connecting plates within the concrete beams are welded to the supporting brackets. Main steel beams are supported on seats which are welded to steel elements embedded in the columns. Steel beams are fastened to the columns by erection bolts and small steel plates welded to the top of the beam and to the column.

Columns transmit the floor loads vertically to the foundation. The columns shown in figures 4 and 5 are continuous from foundation to roof with the exception of some minor eighth story and penthouse columns supporting the walls and roof of the penthouse. Most columns (all below the seventh story) are precast reinforced concrete or precast reinforced concrete composite with a steel core. The concrete and composite columns are uniformly 400 millimeters (16 inches) square in cross section and manufactured in one-story lengths. Column elements are connected together 600 millimeters (2 feet) above the floor level on floors one through eight. A schematic view of a typical column connection is shown in figure 6. Precast columns are connected by welding the corner steel reinforcing bars projecting from each column end, and by filling the joint with grout and concrete. Some steel columns are used in the seventh, eighth and penthouse stories.

Precast concrete shear walls provide the intended lateral force resisting system. Heavy lines on the core periphery in figure 4 show the location of the shear walls. The shear walls are shown schematically in figure 8. A shear wall panel is connected to an adjacent column by three welded connections between steel plates embedded in the panel and column respectively. The vertical joints between two shear wall panels, or between a shear wall panel and a column, and the horizontal joints between shear wall panels are designed to be filled with concrete or grout depending upon the configuration.

The exterior masonry walls are supported on separate reinforced concrete frames at basement and first floor levels on all but the north side where the masonry is supported by a precast concrete block wall. The wall system is designed to be self-supporting throughout the building height. Figure 9 shows a horizontal cross section through a typical pair of masonry piers. Alternate masonry piers are located midway between reinforced concrete columns. The piers coincident with reinforced concrete 

columns are composed of building brick masonry anchored to the column and an exterior wythe of facing brick. Figure 10 shows a vertical cross section of the wall system and windows between masonry piers typical of the first through seventh stories. The reinforced concrete spandrel beam is part of the main structural framing and extends into the wall. The parapet walls and cruciformshaped penthouse are shown in figure 1. Triangular snow melting rooms are located at each corner of the building, and the remaining area is open to the sky. Drain pipes from the snow melting rooms run down adjacent to the corner columns.

Masonry partition walls subdivide the core area on a typical floor as shown in figure 11.

\section{LOADING AND RESISTANCE CRITERIA}

The investigation defined loading and resistance criteria for assessing the structural integrity of the Office Building and for recommending remedial measures. The criteria were selected:

1. To provide a level of safety consistent with good practice for U.S. office buildings.

2. To meet criteria specific to the use of this structure as a U.S. Embassy Office Building.

3. To be consistent with local environmental and site conditions.

4. To account for the characteristics of the Soviet structural system (which differ from those encountered in the United States) and the physical properties of the materials used in the construction of the Office Building.

The Office Building is not assessed in light of Soviet design criteria and accepted Soviet construction practices. The former are not necessarily relevant to U.S. requirements; the latter are neither necessarily relevant nor were they available to the investigators.

Good practice for U.S. office buildings is defined by documents issued by the following organizations: the American National Standards Institute (ANSI) [2] for design loads; the American Concrete Institute (ACI) [3] for resistance of concrete members; the American Institute of Steel Construction (AISC) [4] for steel members; the Brick Institute of America (BIA) [5] for resistance of brick masonry; and the International Conference of Building Officials (ICBO) [6] for foundation pile resistance. Special requirements for U.S. Embassy Office Buildings are provided by the Department of State Office of Foreign Buildings Operations (FBO). The 1968 FBO criteria [7] were in use at the time of the design. Subsequent FBO criteria are dated 1983 [8], and 1986 [9]. The 1986 FBO criteria are considerably more stringent than those of 1968 and 1983 . Since the application of the 1986 criteria to the Office Building and its site has not been required by the State Department, these criteria are not used in this assessment. The criteria used in this assessment are in substantial agreement with the 1983 FBO criteria.

For consistency with local environmental and site conditions, information was obtained from Soviet documents $[10,11]$ on wind and seismic loadings. Soviet design documentation for the Office Building supplied by FBO was used for physical properties of materials and the loads resulting from their weights.

Floor loading criteria were selected in conformance with ANSI [2] using the heavier-than-minimum office floor loading called for by FBO [8]. Live loads for a member were reduced as a function of the area it supports in accord with ANSI [2]. Wind loads conform to ANSI [2] requirements; these exceed the loading called for by the relevant Soviet standard [10]. Snow loading for Moscow [10] is much less than the roof loading specified by FBO [7]; the latter was used. Earthquake loadings are not used in Moscow in Soviet practice [11]. The U.S. Geological Survey advised that neither 
historical records nor seismicity of the Moscow region show hazards from strong earthquake shaking [12]. As for areas of similar seismic hazard in the United States, Seismic Zone 0 requirements of ANSI [2] were used in this study to provide a reasonable, minimum level of seismic resistance.

Progressive collapse has been of concern since the 1968 collapse of a prefabricated building in England. A local failure caused by a gas explosion in an 18th story apartment propagated up to the top (22nd) story and down to the ground floor. Criteria for avoiding progressive collapse are provided under the heading "General Structural Integrity" by ANSI [2]. General structural integrity is defined as "the quality of being able to sustain local damage with the structure as a whole remaining stable and not being damaged to an extent disproportionate to the original local damage." Consideration of progressive collapse is required by the 1983 and 1986 FBO criteria $[8,9]$. Apparently, progressive collapse was not considered in the original design; the structural system of the Office Building is of a type susceptible to progressive collapse. The criterion adopted for this study is that failure of a structural member should not cause progressive failures beyond one story above or below the original failure nor to the adjacent, similar structural members of the same story. The criterion is to be satisfied by developing alternate paths for the loadings supported by a member that might fail. Such analysis would use ultimate strength characteristics for members in the alternate paths and consider expected, rather than extreme, values for the loadings to be transmitted.

Strengths that were specified for the materials of the Office Building in accord with Soviet practices, were converted into values consistent with the cited U.S. practices. For concrete strength, the conversion involved consideration of the differences between Soviet cube test strengths and U.S. cylinder test strengths and consideration of a different relationship between average and minimum required values for strength. For reinforcing steel, structural steel and welds, Soviet values for specified yield and tensile strengths were used with appropriate conversions from metric to U.S. customary units.

\section{ASSESSMENT OF DESIGN}

The as-designed structure was assessed in terms of the criteria described in Section 3 to guide field and laboratory investigations and to identify potential structural deficiencies. The assessment included the foundation system, the structural frame that supports vertical loads, the shear wall system that resists lateral loads, alternate paths in the event of failure of a structural member, and the performance of the exterior masonry walls in supporting their own weight and in their interactions with the structural frame.

Two analytical approaches were used. Because the beams and floor planks are "simply supported" (connected without ability to transmit large bending forces) a manual approach can be and was used for analysis of the forces in members. This approach was used earlier in the Soviet design calculations. In order to investigate more complex, three dimensional behavior, and deviations from planned structural properties and dimensions, finite element analytical models also were developed for computer analyses.

Review of the foundation system, floor planks, steel beams and their connections showed acceptable design strengths.

Review of the concrete beams and connections showed four sections to be understrength. These were given special attention in field investigations. Review of concrete columns showed a number to be understrength, some by as much as 30 percent. These include composite concrete and steel columns that would require intermediate bracing to increase buckling resistance and reinforced 

concrete columns that lack the required strength based on the specified concrete strength. These were given special attention in field and laboratory investigations.

Review of the shear wall system as designed showed it to be sufficient to resist the design lateral loads provided that the horizontal shear wall joints are properly filled with concrete of specified strength. Because of the sensitivity of the overall performance of the shear wall system to the condition of these joints, they were given special attention in the field investigations.

As designed, the exterior masonry walls are stiffer than the shear walls for stories one through eight. Consequently, the exterior walls rather than the shear walls would attract and conduct lateral forces from wind or earthquake. The exterior masonry walls do not continue through the basement to the foundations. The floor system and shear walls are adequate to transfer the design wind forces from the masonry walls to the foundations.

Review of the floor planks and long span steel beams for alternate load paths to avoid progressive collapse showed that individual failures of floor planks or beams on floors one through seven would not be likely to cause failures of adjacent members or members below. However, failures of a major beam on the eighth floor, or of some individual columns in the core area from the basement to the eighth floor, might lead to progressive collapse in the structure as designed. Attention to avoidance of progressive collapse is provided in Section 6.

Stresses in the masonry facade were investigated using material properties obtained from specimens taken at the site and specimens obtained from the U.S. manufacturer of the facing brick. The analyses show that stresses induced by movements of the brick masonry and the structural frame may be large enough to account for cracking in the masonry. Further studies are recommended in Section 6.

The parapet walls do not meet the requirements of U.S. building codes [6] for unreinforced masonry and do not meet ANSI [2] criteria for lateral force resistance. Remedial measures are given in Section 6.

\section{SITE AND LABORATORY INVESTIGATIONS}

Two site visits were made to the Office Building. The first occurred from December 17 to 19 , 1986. The purpose was to study the structure and its condition to assist in planning a detailed site investigation. The second visit took place from February 17 to March 6, 1987. It involved a detailed investigation of the structural system and the building envelope. Various material samples were obtained, shipped to NBS and tested to provide data for the assessment.

The load-bearing system is, on the whole, constructed as expected from the review of design and construction documents. No significant deficiencies were noted in the structural steel elements. In-place hardness tests and laboratory tests of steel samples gave no indications that materials of less-than- specified strengths were used. Examinations of welded connections revealed general conformance with the design. Tests of core samples taken from various reinforced concrete members indicated strengths in excess of the specified values.

The as-built conditions of some joints between precast elements were found to have significant deviations from the design. Notable among these were the incompletely grouted and concreted joints between segments of reinforced concrete columns. Some of these were immediately visible as shown in figure 12. Other defective joints were concealed by surface concreting of the joint but were revealed by drilling and viewing with a borescope. Figure 13 shows an interior view of an ungrouted joint and indications of distress at the seating button at the end of the column 
segment. Laboratory tests at NBS on facsimilies of complete and incomplete joints, figure 14, show that strength is degraded as much as 56 percent by incompletely grouted and concreted joints. Deficiencies also were found in completion of the vertical joints, figure 15, and horizontal joints, figure 16, between shear wall panels. Few of the shear wall joints investigated were properly grouted and concreted. The bond between the topping and the floor planks was assessed by sounding and coring at a number of locations. In no core sample was the topping soundly bonded to the floor plank.

A detailed visual examination of the exterior brick masonry walls was performed from ground level and by descending the building (see cover photograph). The exterior walls showed vertical cracking on all four sides of the building. An example is shown in figure 17. Vertical cracks on two of the corners run from ground elevation to the top of the seventh story. Vertical cracks were seen in five piers between windows at the second story columns. The most severe horizontal cracking occurs in the parapet walls, all of which have horizontal cracks either on the inside, the outside, or on both sides. An example is shown in figure 18. Vertical cracks also were noted in the parapet walls. The penthouse walls show both horizontal and vertical cracks, but they are fewer in number and smaller in size than the parapet cracks.

Inspection of the brick partitions in the core area revealed that many of these walls are either unfinished or otherwise incomplete at the top so that they are not tightly built in with the building structure. Wall specimens and individual Soviet-produced bricks were brought back to the NBS laboratories for testing to provide physical property information needed for analyzing the as- built construction.

Site investigation also indicated that fireproofing is missing at a number of beam-to-column connections. Insulation is placed improperly in some corner piers and threatens to allow freezing of the drains for the snow-melt areas of the roof. The cavities above the windows are not insulated. This allows ice build-up and possible damage to the windows and walls.

\section{ASSESSMENT OF THE EXISTING STRUCTURE AND RECOMMENDATIONS FOR REMEDIAL MEASURES}

Deficiencies identified in review of the design or in site investigations have been assessed and remedial measures defined as needed to achieve required performance. Cost estimates to accomplish the remedial measures have been provided by Turner International [13] on the basis of costs for similar work done in Washington, D.C.

The floor planks were determined to possess adequate strength as designed. However, to improve the resistance to progressive collapse in the event of failure of a major beam, it is important that the topping remain suspended rather than allowing contents to fall to the floor below. This can be achieved by fastening the topping to the beams along portions of the east and west exterior walls on floors two through seven. The estimated cost for this remedial measure is $\$ 109,000$.

All steel beams and connections were designed for adequate resistances and no deficiencies in materials or fabrication were identified at the site. However, were a major eighth floor beam to fail and fall, along with the heavy floor it supports, onto the seventh floor, a progressive collapse might occur. This can be avoided by fastening a system of steel straps perpendicular to the top flanges of major eighth floor beams so that if one were to fail it would remain suspended. The estimated cost for this remedial measure is $\$ 78,000$.

Four concrete beams were indicated to be underdesigned. None is expected to be subjected to large live loads from occupancy and none shows signs of distress. The loads come mostly from masonry 
partitions that arch over the midspan regions of the beams to reduce the bending. Therefore, no remedial measures are recommended.

The design review showed a number of reinforced concrete columns to be overloaded. However, core tests showed higher-than-specified concrete strengths giving adequate levels of resistance. Four steel-core columns are inadequately braced against buckling. They can be firmly attached to adjacent masonry walls to provide the required bracing. The estimated cost for this remedial measure is $\$ 1,000$.

Site investigation showed that the integrity of all joints of reinforced concrete columns is questionable. Laboratory studies showed that failure to place grout and concrete in the joint severely reduces the column strength. Each such joint should be exposed and drilled to determine whether the joint area is filled with grout and concrete, and each deficient joint should be filled. The estimated cost for this remedial measure is $\$ 132,000$.

Site investigation showed that few observed shear wall joints were grouted and concreted in accord with the plans and with the requirements for appropriate strength and stiffness. Each vertical and horizontal joint of each shear wall panel should be exposed, inspected for complete grouting and concreting of the joint, and filled if needed. The estimated cost for this remedial measure is $\$ 155,000$.

Consideration of the potential for progressive collapse showed that alternate load paths are not presently available in the event of the failure of some columns in the core area of the building. Gaps between masonry walls and adjacent beams and columns should be filled and the walls strengthened to provide the needed alternate load paths. The estimated cost is $\$ 263,000$.

Parapet walls should be taken down to a level below substantial horizontal cracking, anchored to the structural system below, and restored with properly designed and constructed masonry. The estimated cost for this remedial action is $\$ 385,000$.

The following remedial measures should be made to improve the serviceability and durability of the Office Building.

Site investigation showed substantial cracking in the exterior masonry walls. Vertical expansion joints should be provided in the corner piers to allow for differential movement and sealed to prevent entrance of moisture. The estimated cost for this remedial measure is $\$ 22,000$.

The site investigation showed vertical cracks in the masonry walls. The scope of this investigation did not permit a definitive determination of their cause. They may result from excessive vertical compressive stress leading to vertical splitting. A program should be conducted for long-term monitoring of these cracks to determine whether they are growing in extent or number. From these observations and further analyses, appropriate remedial measures can be formulated, if required. For a two-year program, the estimated cost is $\$ 200,000$.

Cracked penthouse walls should be taken down to a level below substantial cracking and properly rebuilt. The estimated cost for this remedial action is $\$ 94,000$.

Insulation should be placed appropriately in corner piers and in cavities above windows. The estimated cost for this remedial action is $\$ 25,000$. 



\section{References}

[1] Carino, N.J.; Gross, J.G.; Stone, W.C.; Sansalone, M.J.; Yokel, F.Y.; Simiu, E.; Hendrickson, E.M.; Mathey, R.G.; Scribner, C.; Wright, R.N. Structural Assessment of the New U.S. Embassy Office Building in Moscow. National Bureau of Standards, NBSIR 87-3637; April 1987.

[2] Minimum Design Loads for Buildings and Other Structures American National Standards Institute. ANSI A58.1-1982.

[3] Building Code Requirements for Reinforced Concrete. American Concrete Institute. ACI 318-83.

[4] Load and Resistance Factor Design. American Institute of Steel Construction. First Edition, 1986.

[5] Building Code Requirements for Engineering Brick Masonry. Brick Institute of America. 1969.

[6] Uniform Building Code. International Conference of Building Officials. May 1985.

[7] Engineering Design Criteria. Department of State, Office of Foreign Buildings Operations. April 1968.

[8] Planning Procedures and Engineering Criteria. Department of State, Office of Foreign Buildings Operations. October 1983.

[9] Architectural and Engineering Design Guidelines and Criteria for New Embassy Buildings. Department of State, Office of Foreign Buildings Operations. November 1986.

[10] Soviet Standard SNiP II-6-74. Construction Standards and Regulations, Part II Design Standards, Chapt. 6, Loads and Actions. Moscow, Stroizdat. 1976.

[11] Soviet Standard SNiP II-A.12-69*. Construction Standards and Regulations, Part II Design Standards, Chapt. 12, Construction in Seismic Regions. Moscow, Stroizdat. 1977.

[12] Leith, W. Personal Communication. U.S. Department of Interior, Geological Survey. 13 March 1987.

[13] U.S. Embassy Moscow Remedial Work. Turner International Industries, Inc. April 1987. 


\section{INDEX OF FIGURES}

Figure 1 Architectural Rendering of the Embassy Site

Figure 21982 Photograph of East Elevation of Structure

Figure 3 Office Building in December 1986 from the Southwest

Figure 4 Structural Plan

Figure 5 Section Through Building

Figure 6 Schematic of Structural Elements at a Core Column

Figure 7 Plan Showing Beam Layout of Typical Floor

Figure 8 Schematic View of Precast Shear Wall Assembly

Figure 9 Typical Piers at and Between Columns

Figure 10 Typical Window Head and Sill Section

Figure 11 Partition Plan of Core (Floors 2-7)

Figure 12 Defective Joint for Column D1/4A

Figure 13 Borescope Photograph Inside Joint Showing Evidence of Distress in Seating "Button" Due to Lack of Grout

Figure 14 NBS Test of Colurnn Joint

Figure 15 Open Shear Wall to Column Joint

Figure 16 Incomplete Filling of a Horizontal Shear Wall Joint

Figure 17 Cracks on South Elevation

Figure 18 Horizontal Cracks in South Face of Parapet Wall 


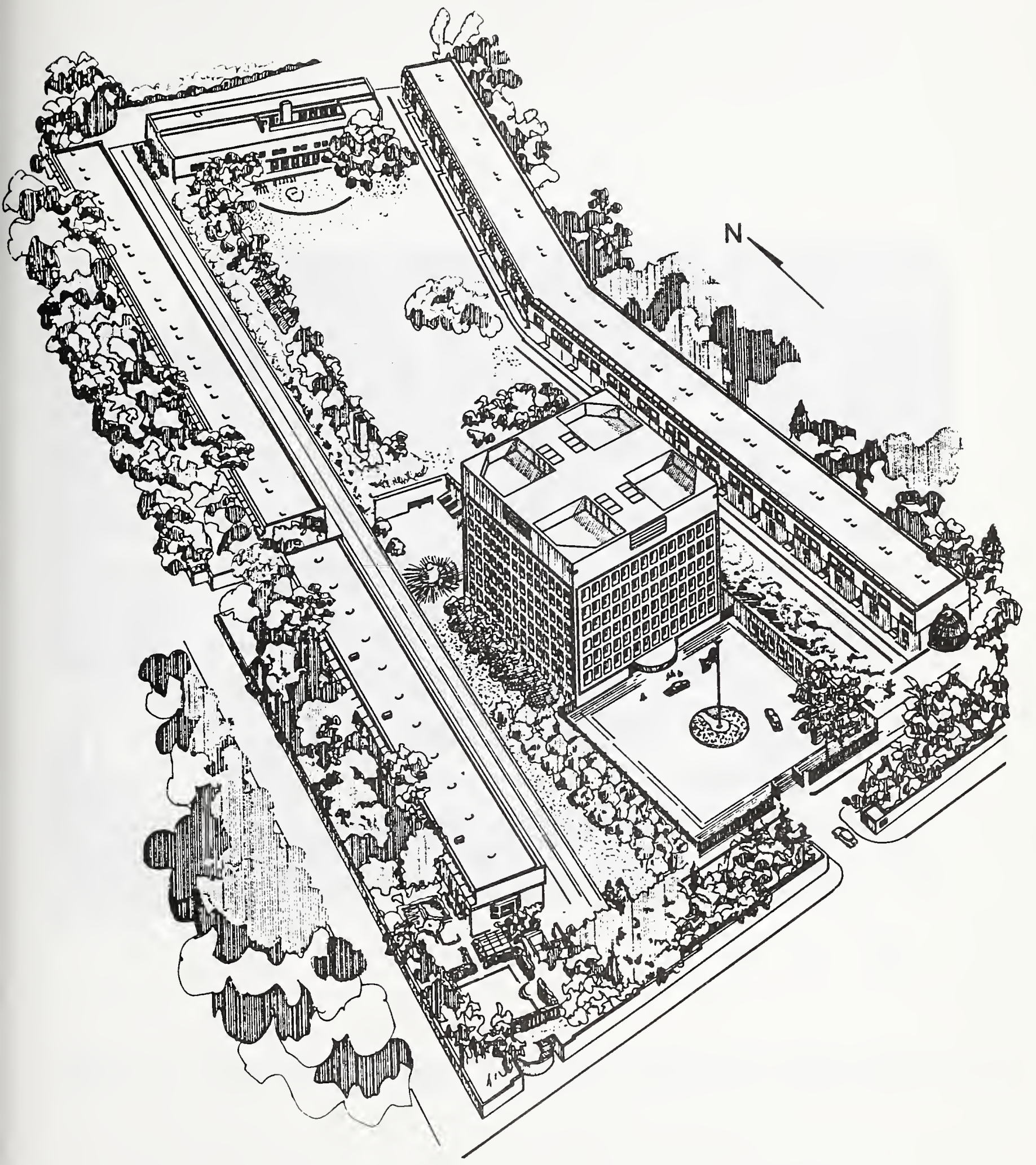

Figure 1 ARCHITECTURAL RENDERING OF THE EMBASSY SITE 



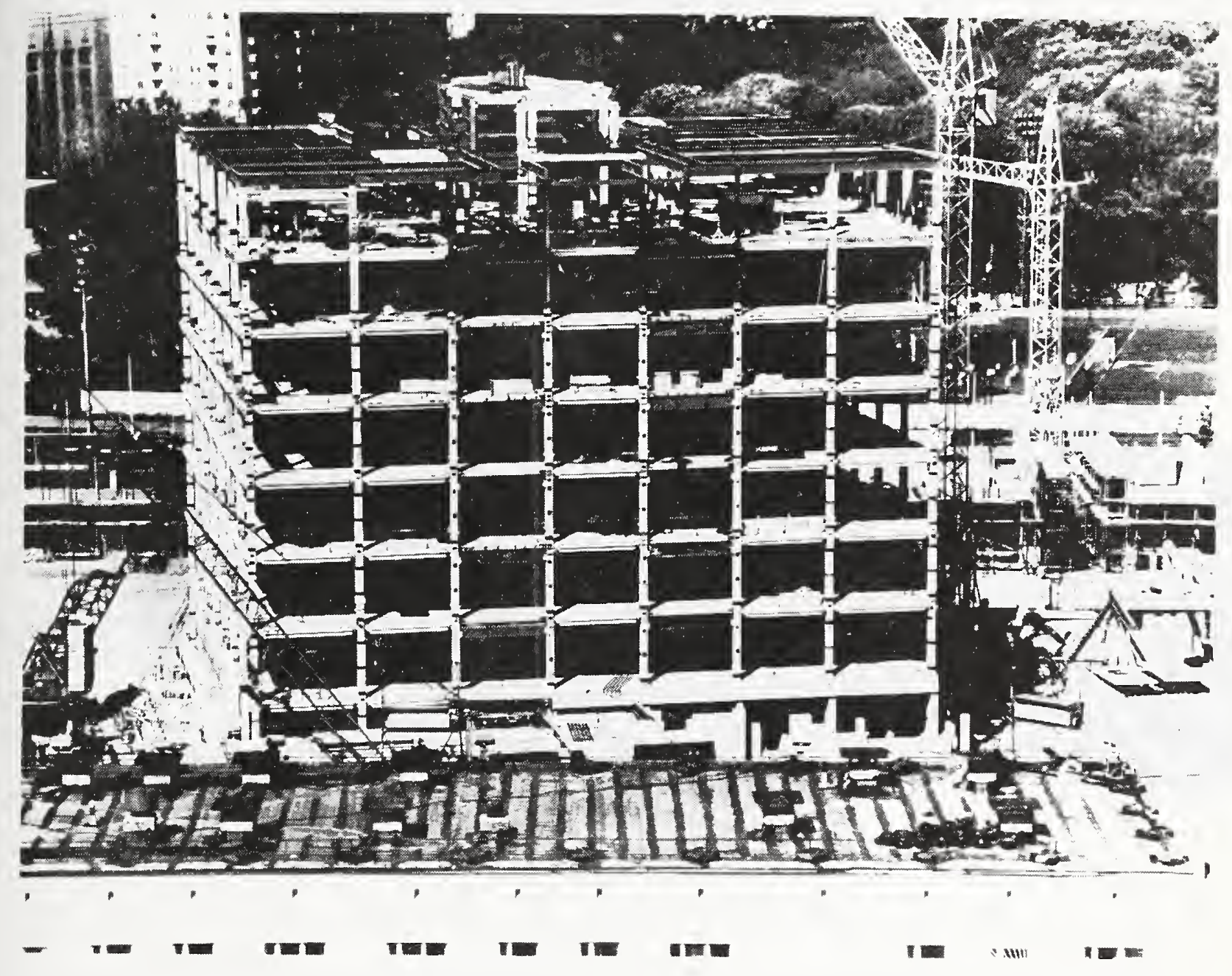

Figure 21982 PHOTOGRAPH OF EAST ELEVATION OF STRUCTURE 


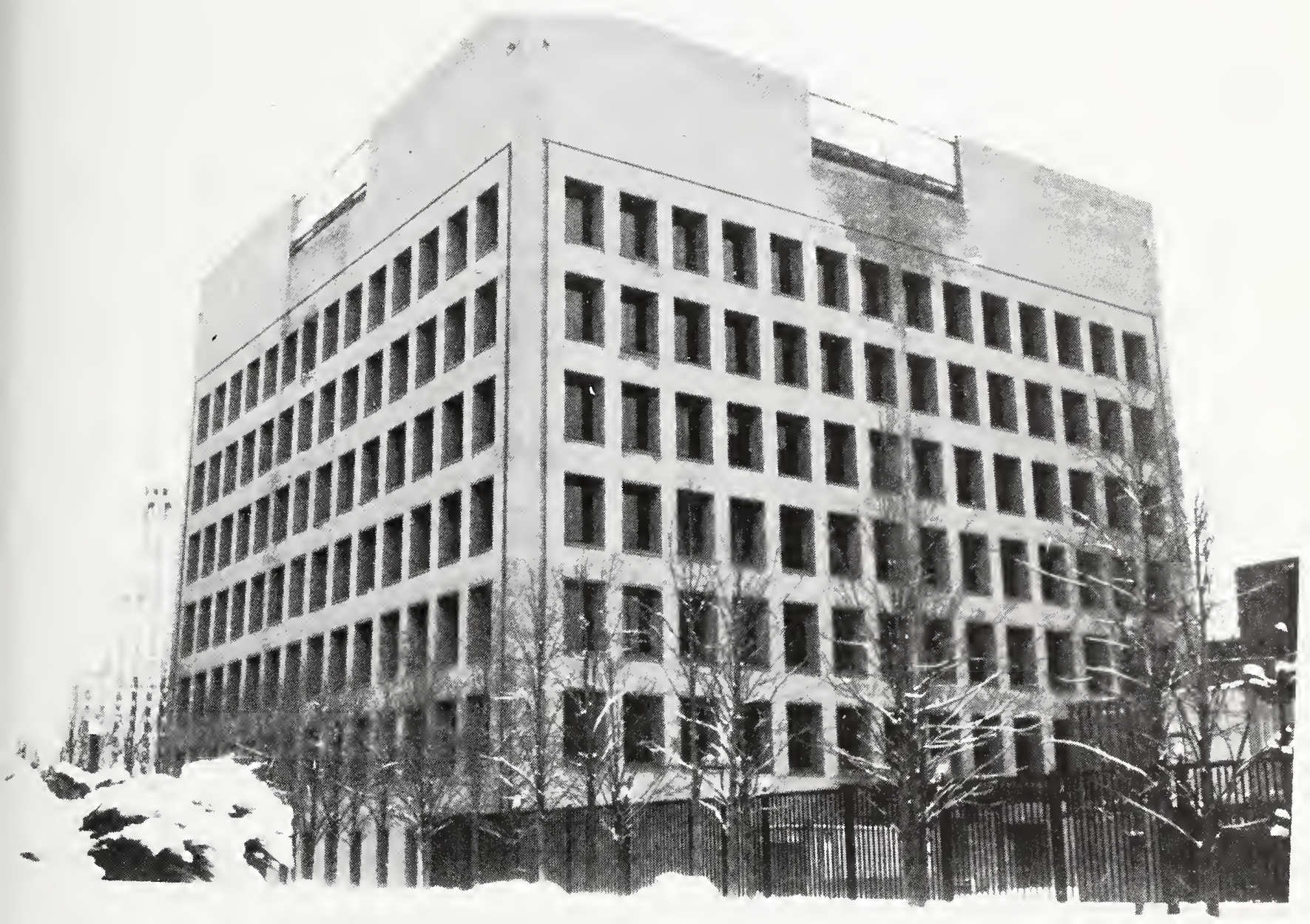

Figure 3 OFFICE BUILDING IN DECEMBER 1986 FROM THE SOUTHWEST 


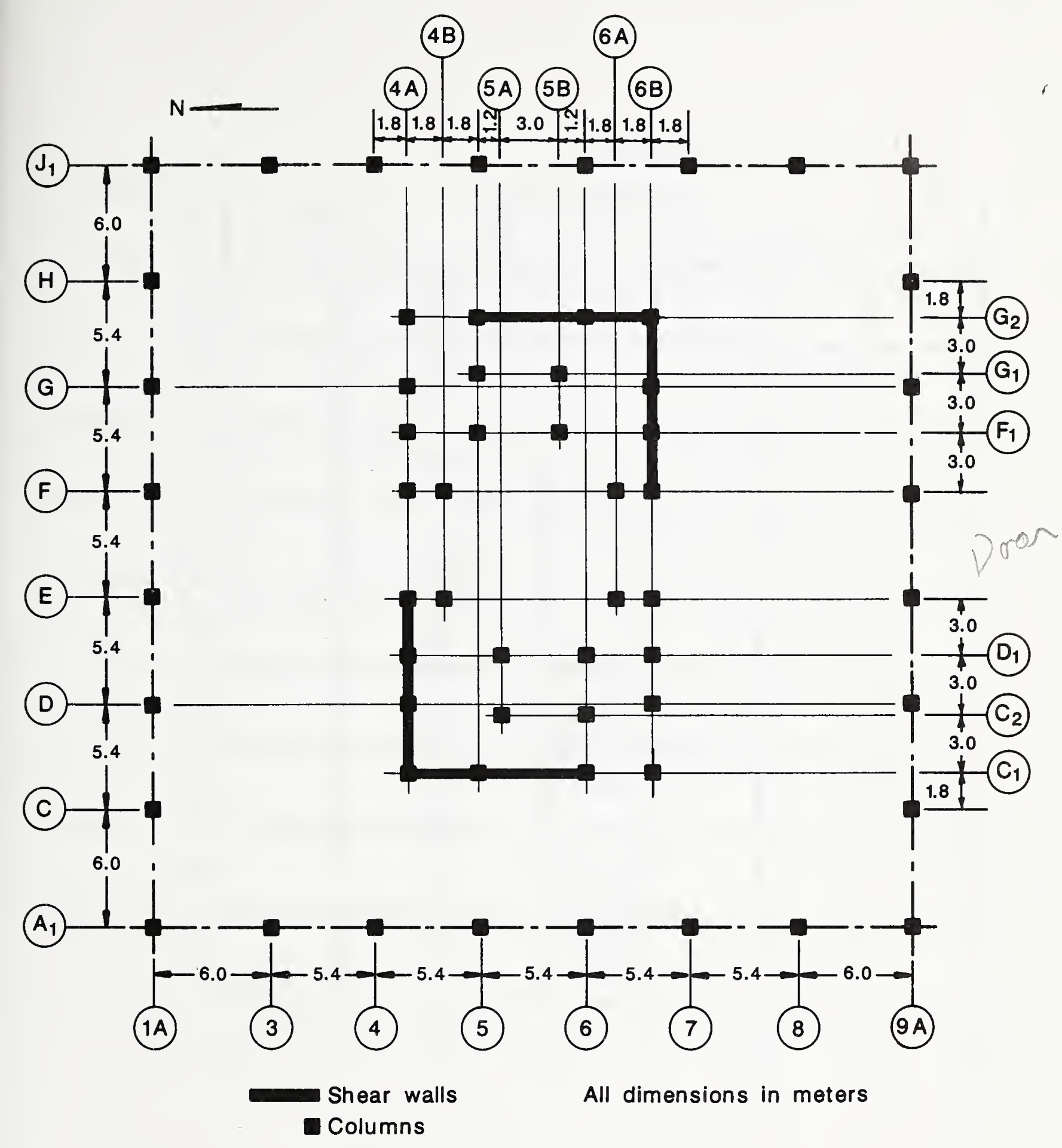

Figure 4 STRUCTURAL PLAN 

All dimensions in meters

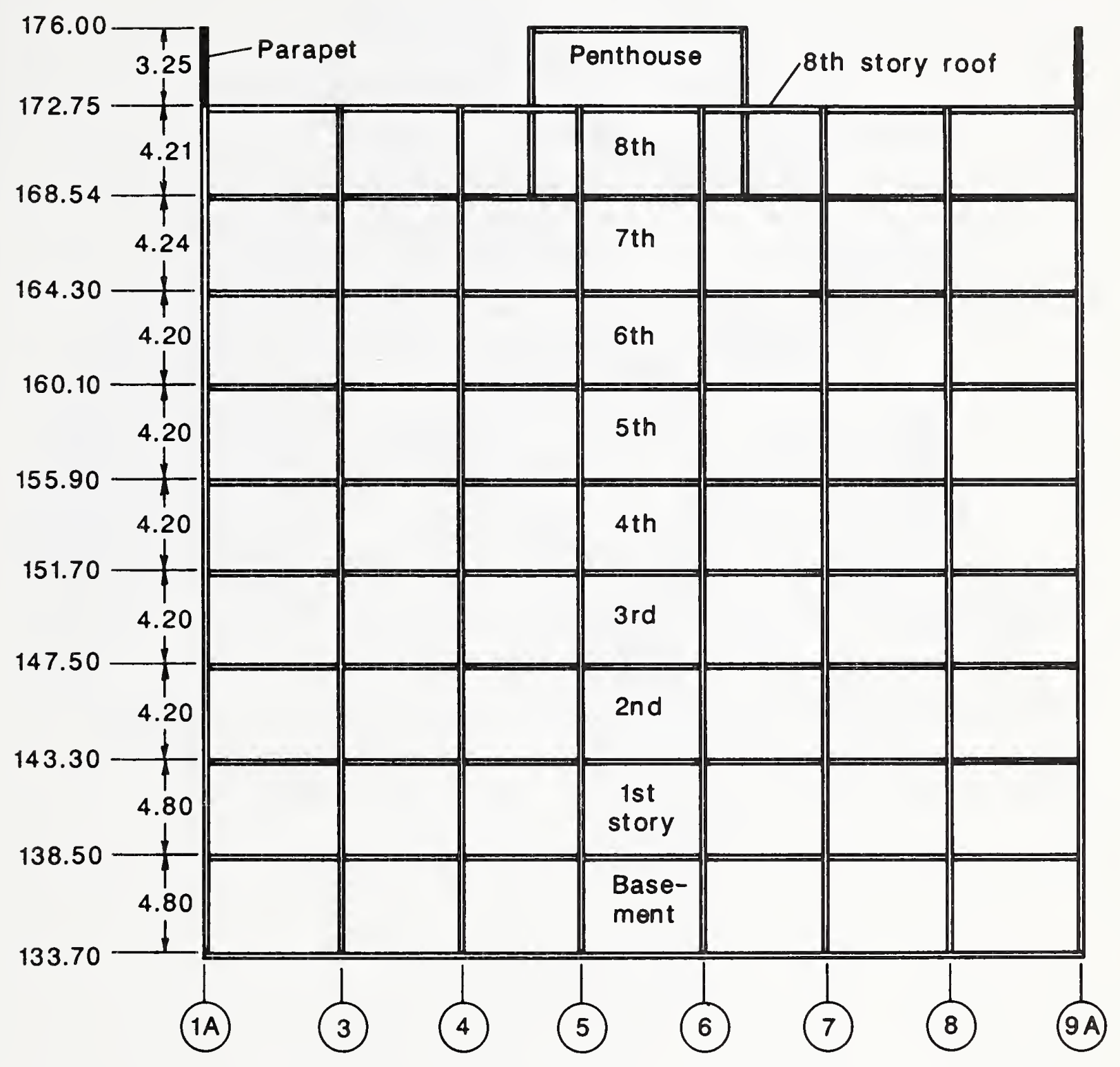

Figure 5 SECTION THROUGH BUILDING 


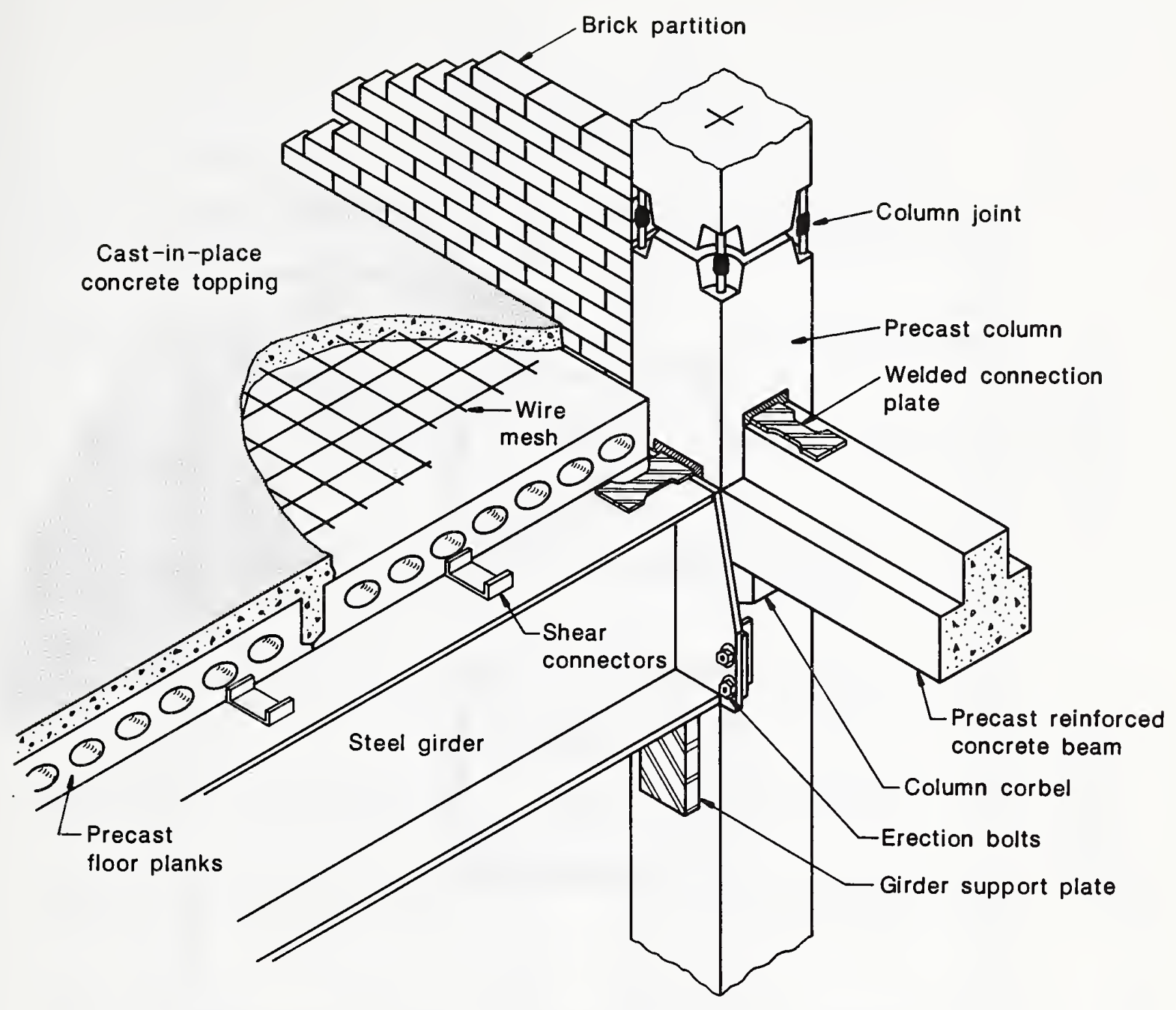

Figure 6 SCHEMATIC OF STRUCTURAL ELEMENTS AT A CORE COLUMN 



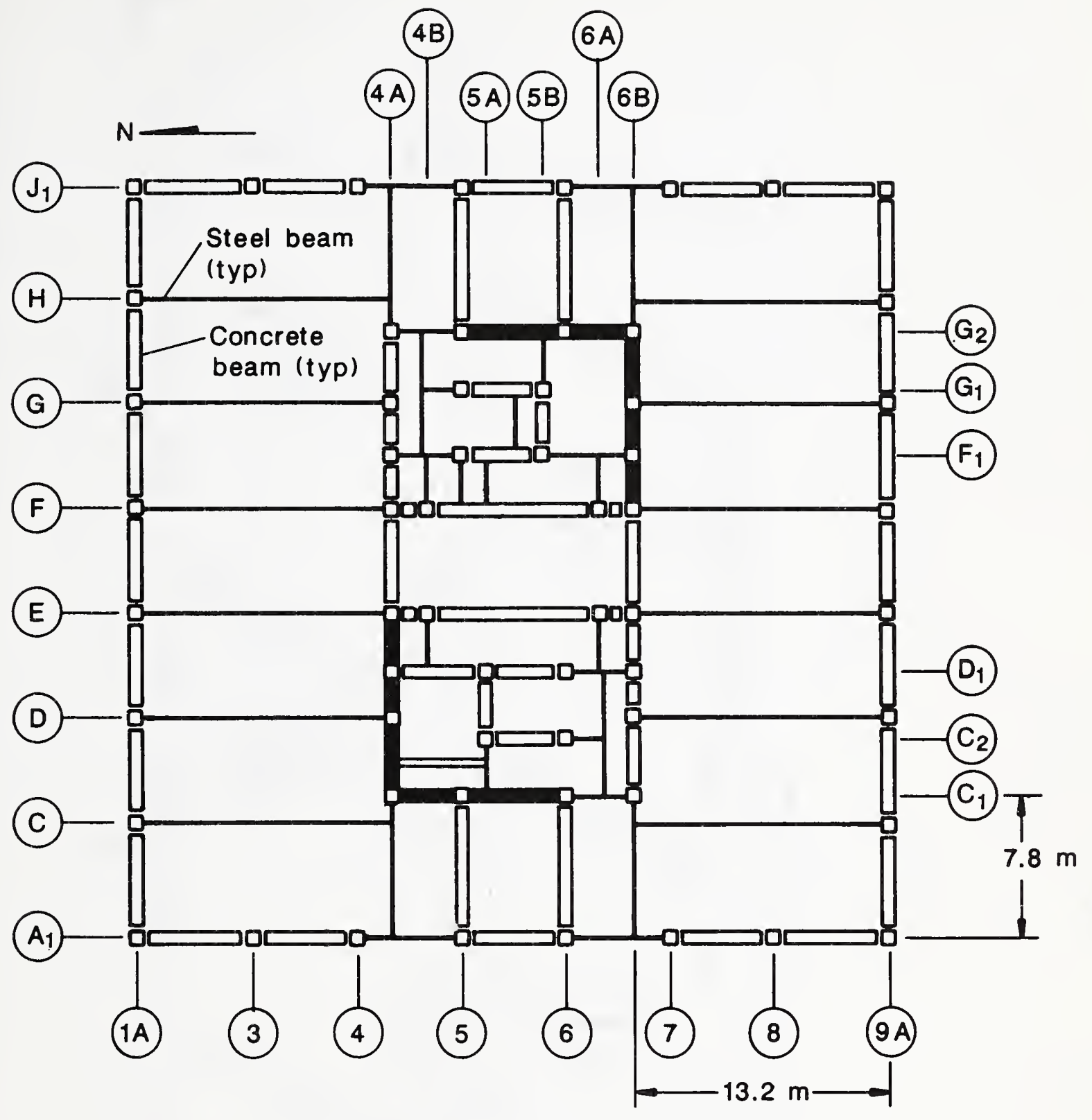

Figure 7 PLAN SHOWING BEAM LAYOUT OF TYPICAL FLOOR 



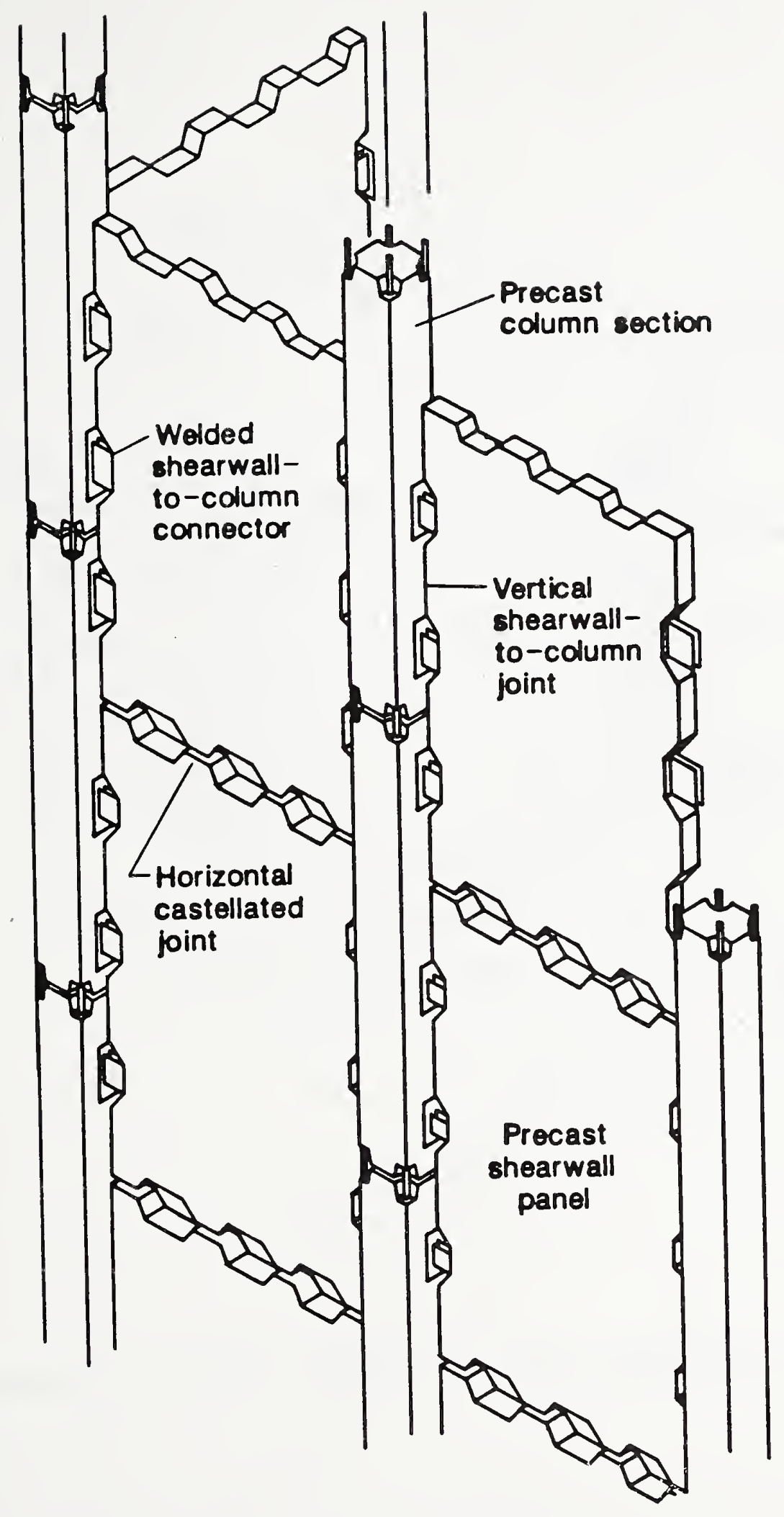

Figure 8 SCHEMATIC VIEW OF PRECAST SHEAR WALL ASSEMBLY 


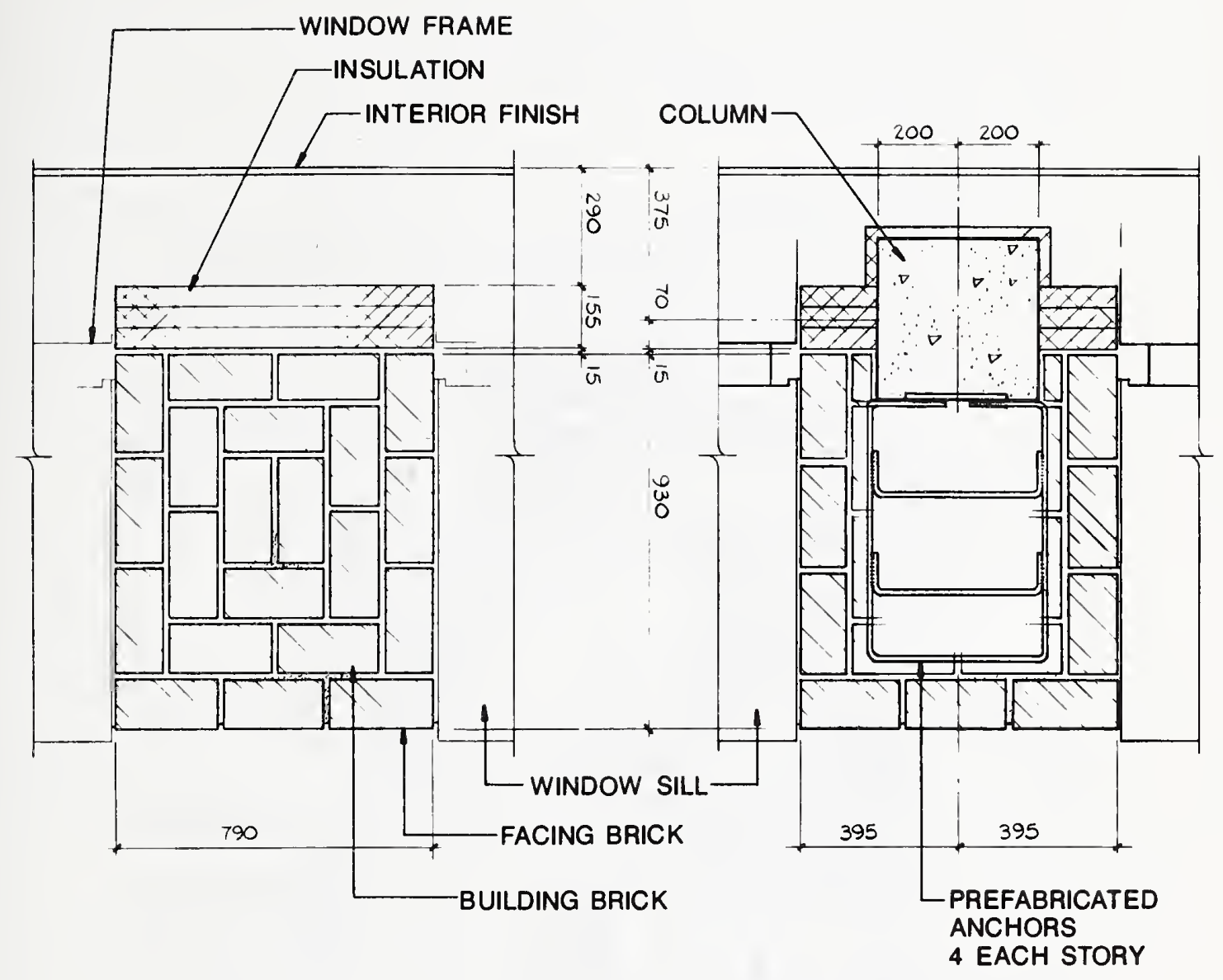

Figure 9 TYPICAL PIERS AT AND BETWEEN COLUMNS 


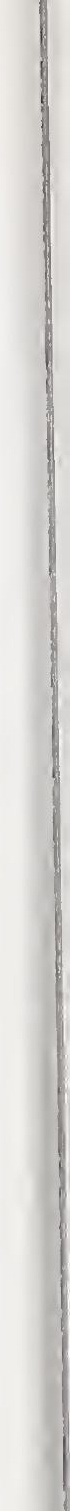




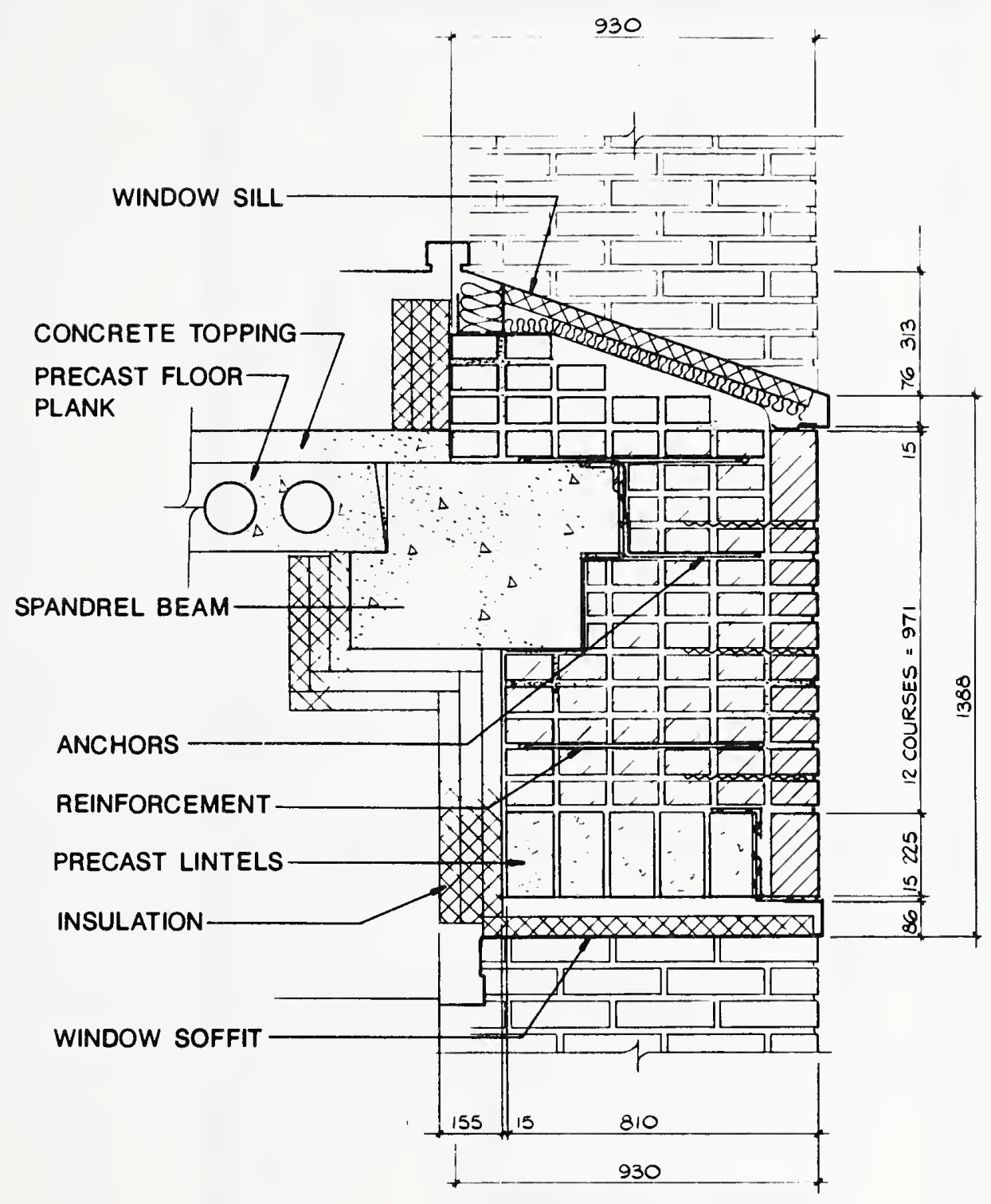

Figure 10 TYPICAL WINDOW HEAD AND SILL SECTION 


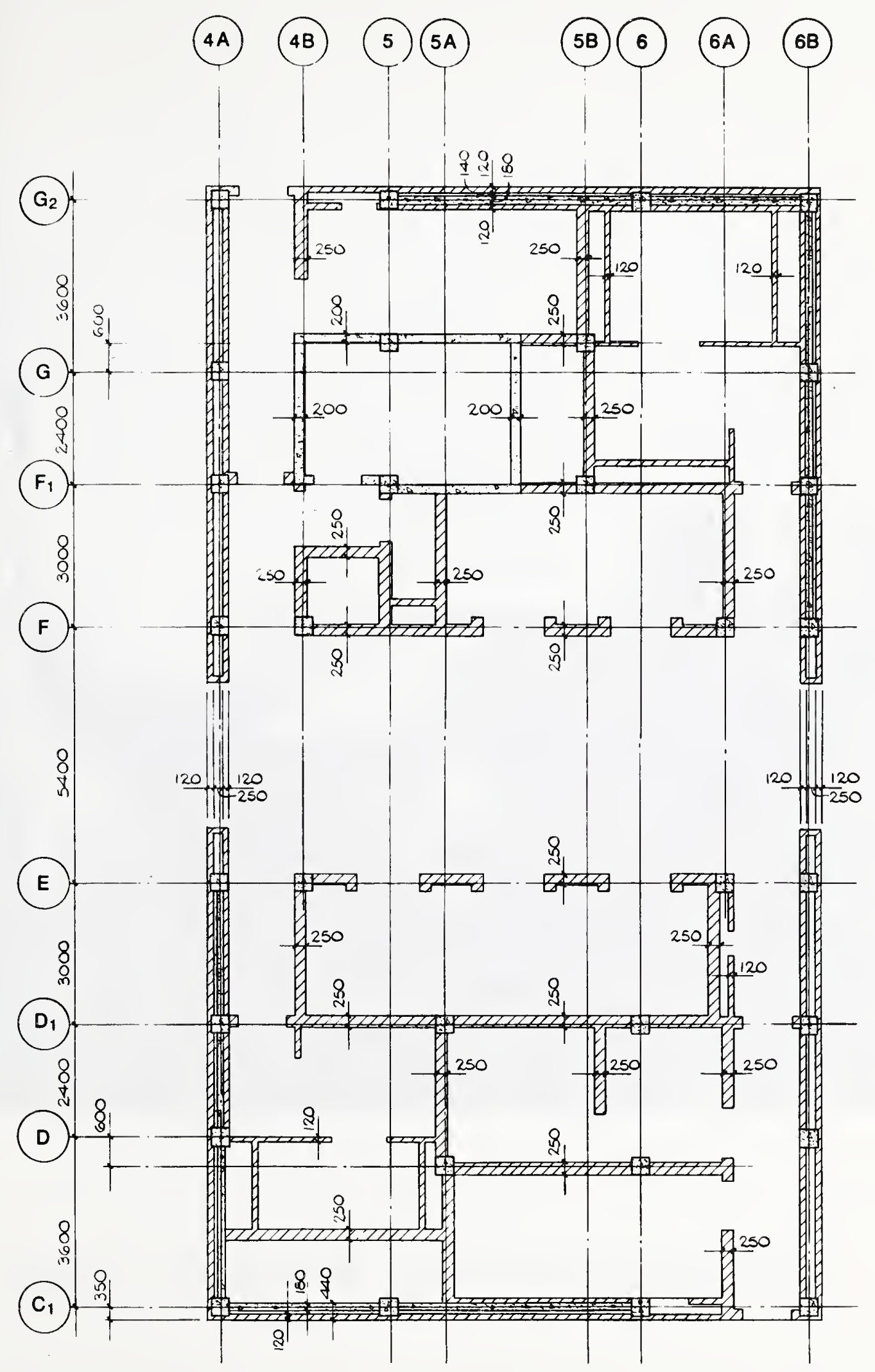

Figure 11 PARTITION PLAN OF CORE (Floors 2-7) 


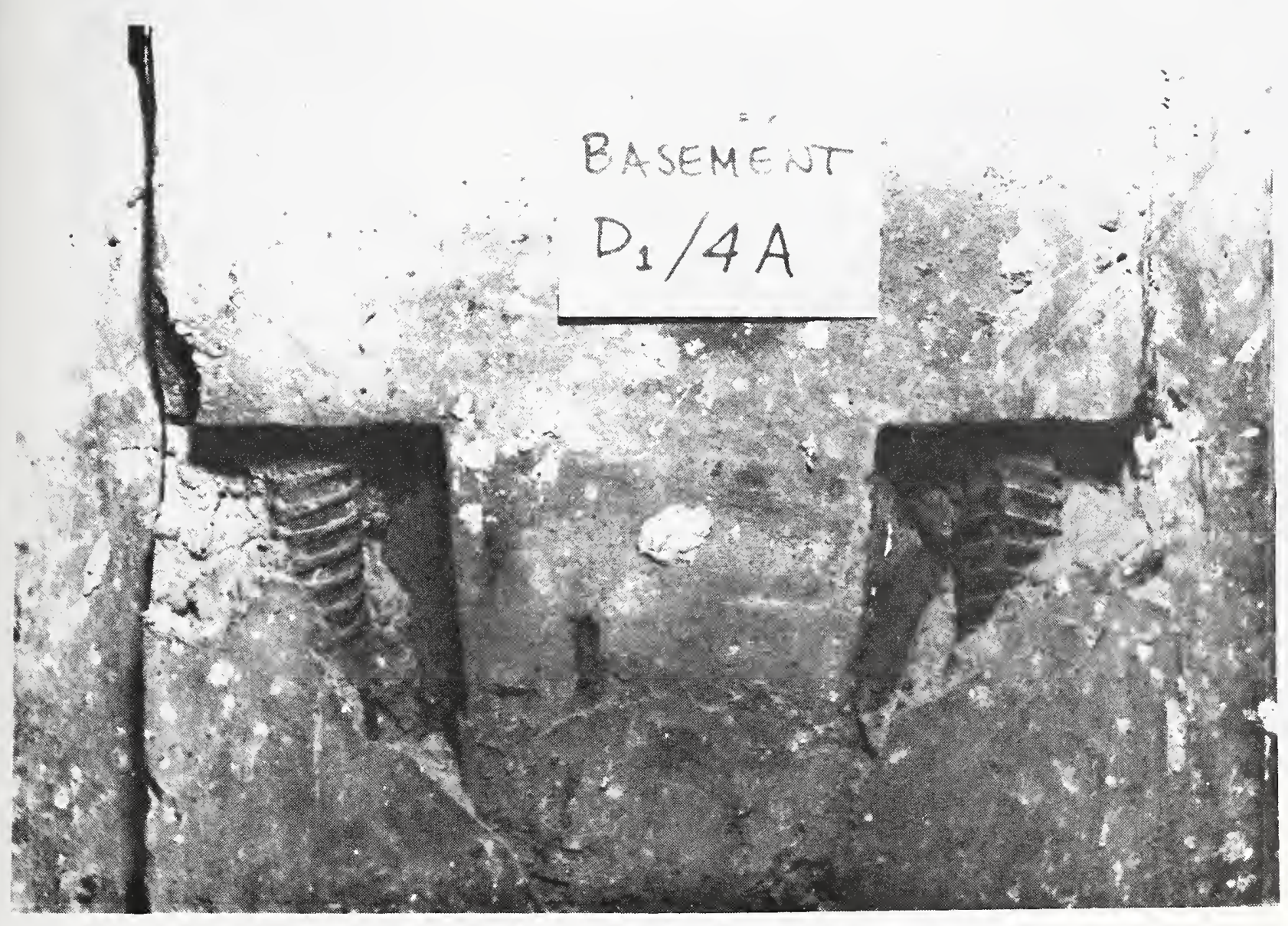

Figure 12 DEFECTIVE JOINT FOR COLUMN D1/4A 


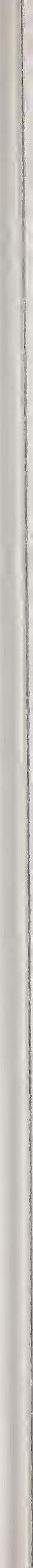



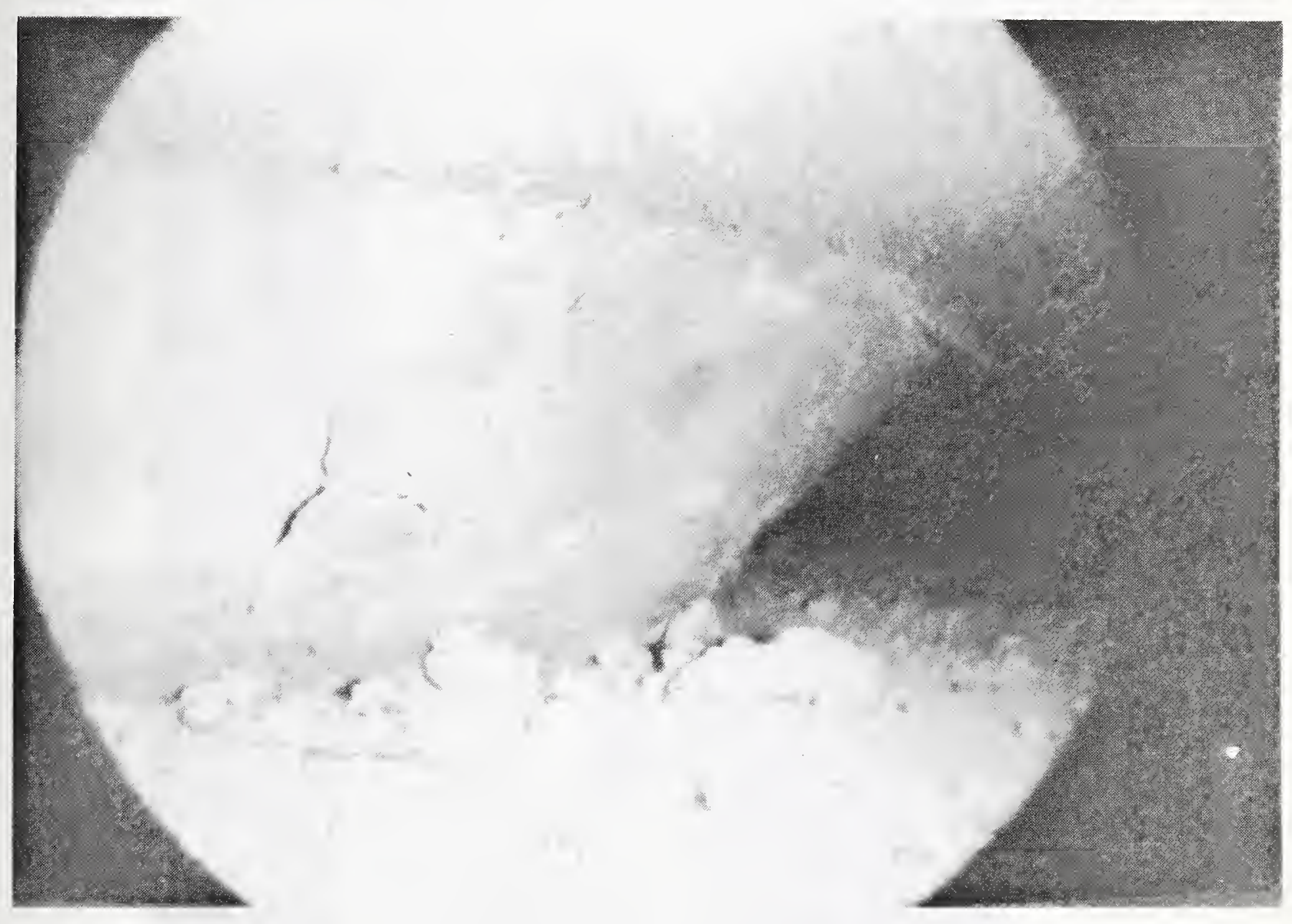

Figure 13 BORESCOPE PHOTOGRAPH INSIDE JOINT SHOWING EVIDENCE OF DISTRESS IN SEATING "BUTTON" DUE TO LACK OF GROUT 


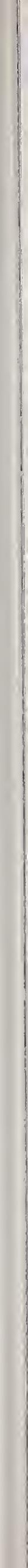




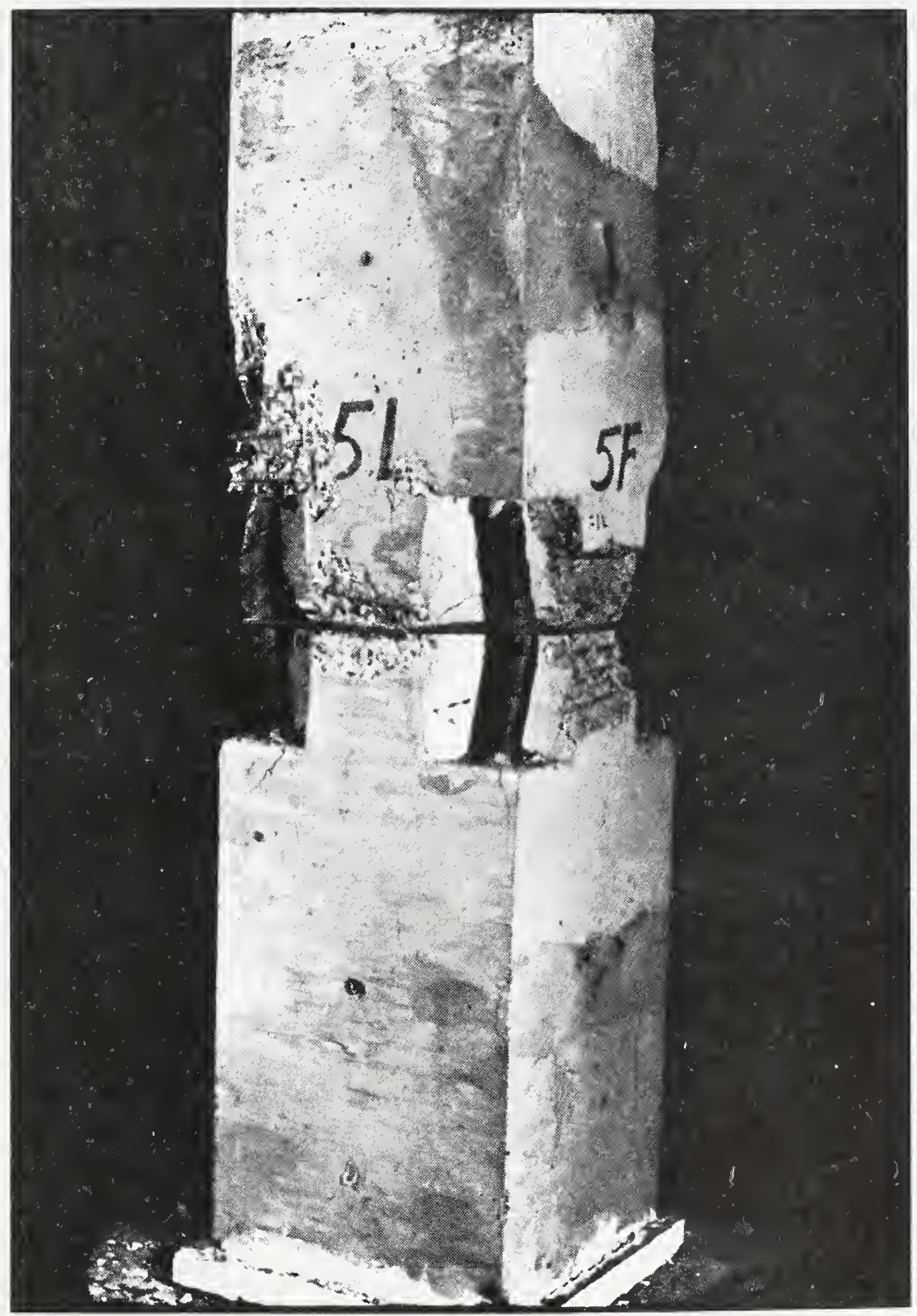

Figure 14 NBS TEST OF COLUMN JOINT 


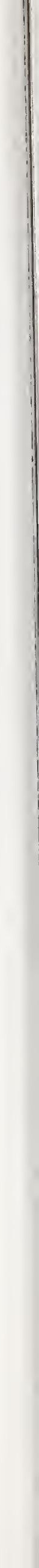




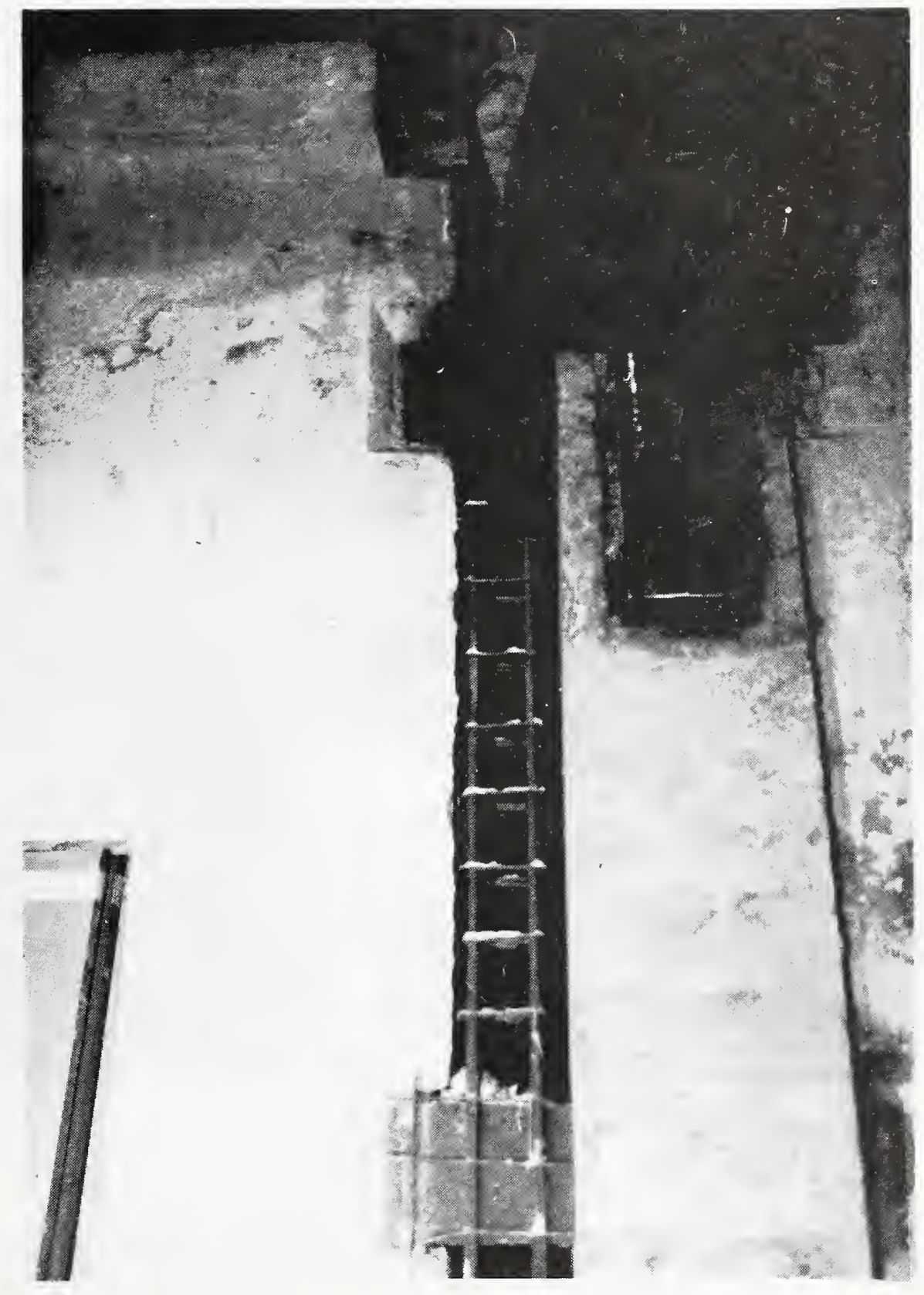

Figure 15 OPEN SHEAR WALL TO COLUMN JOINT AT COLUMN 


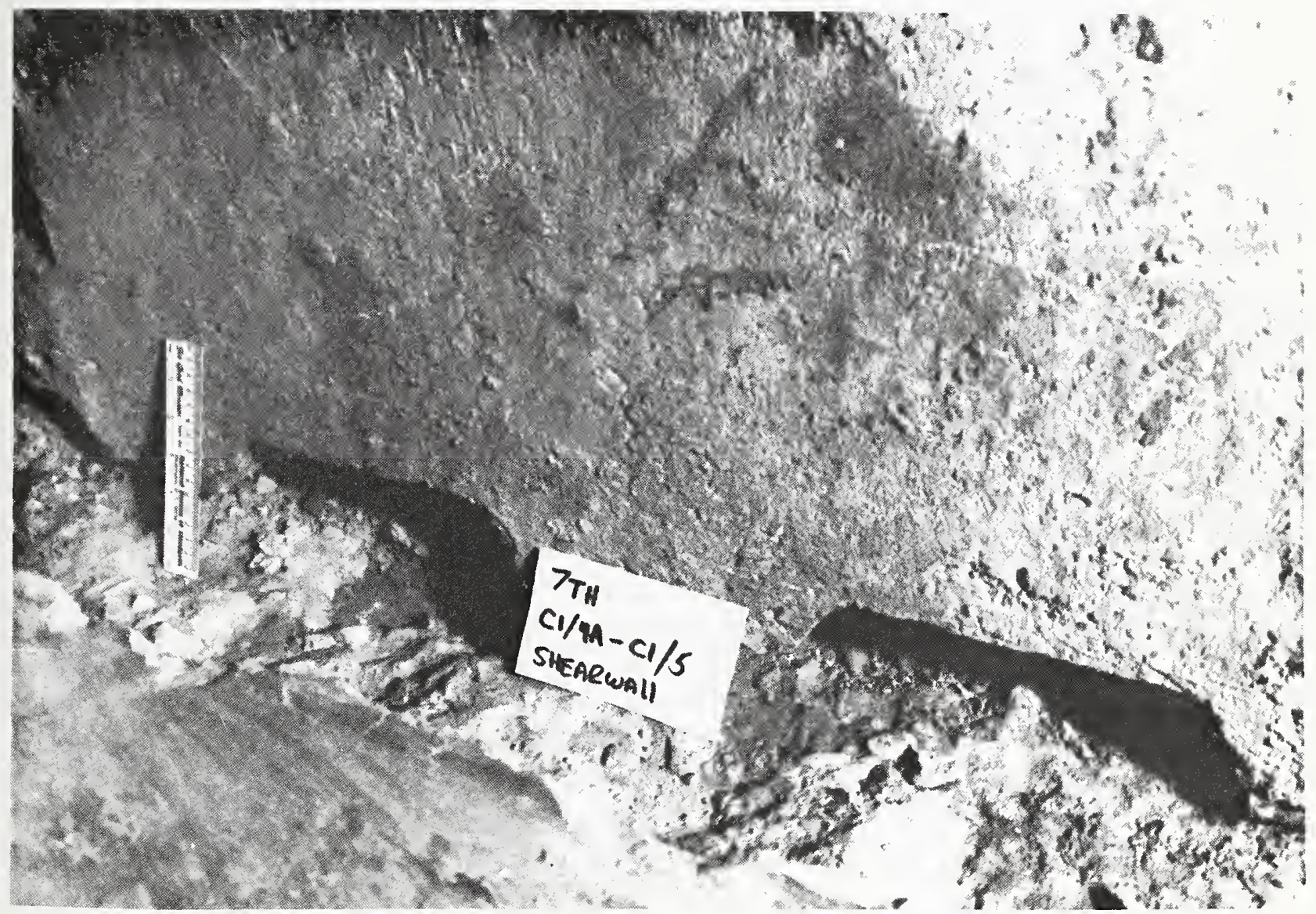

Figure 16 INCOMPLETE FILLING OF A HORIZONTAL SHEAR WALL JOINT 


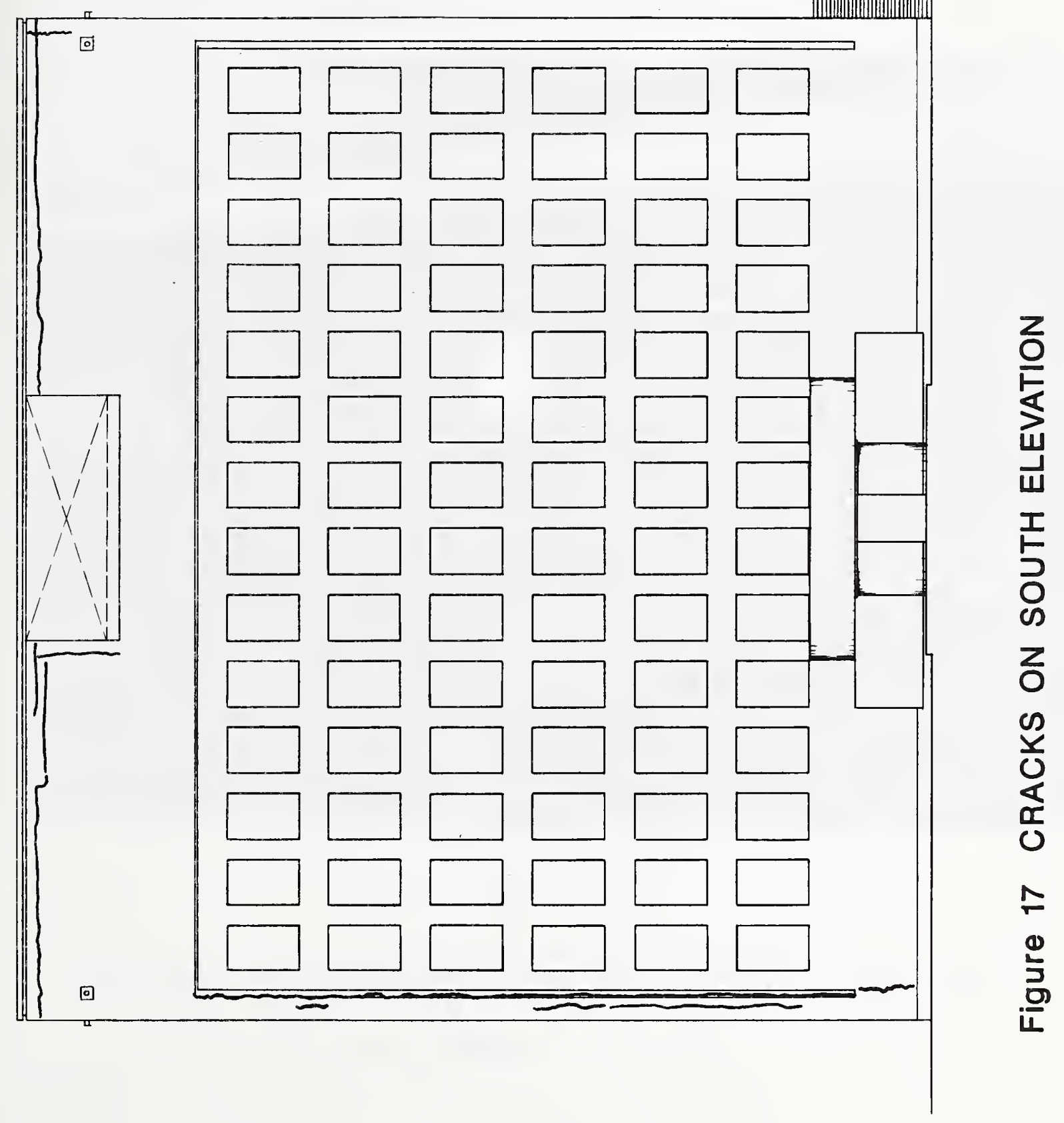




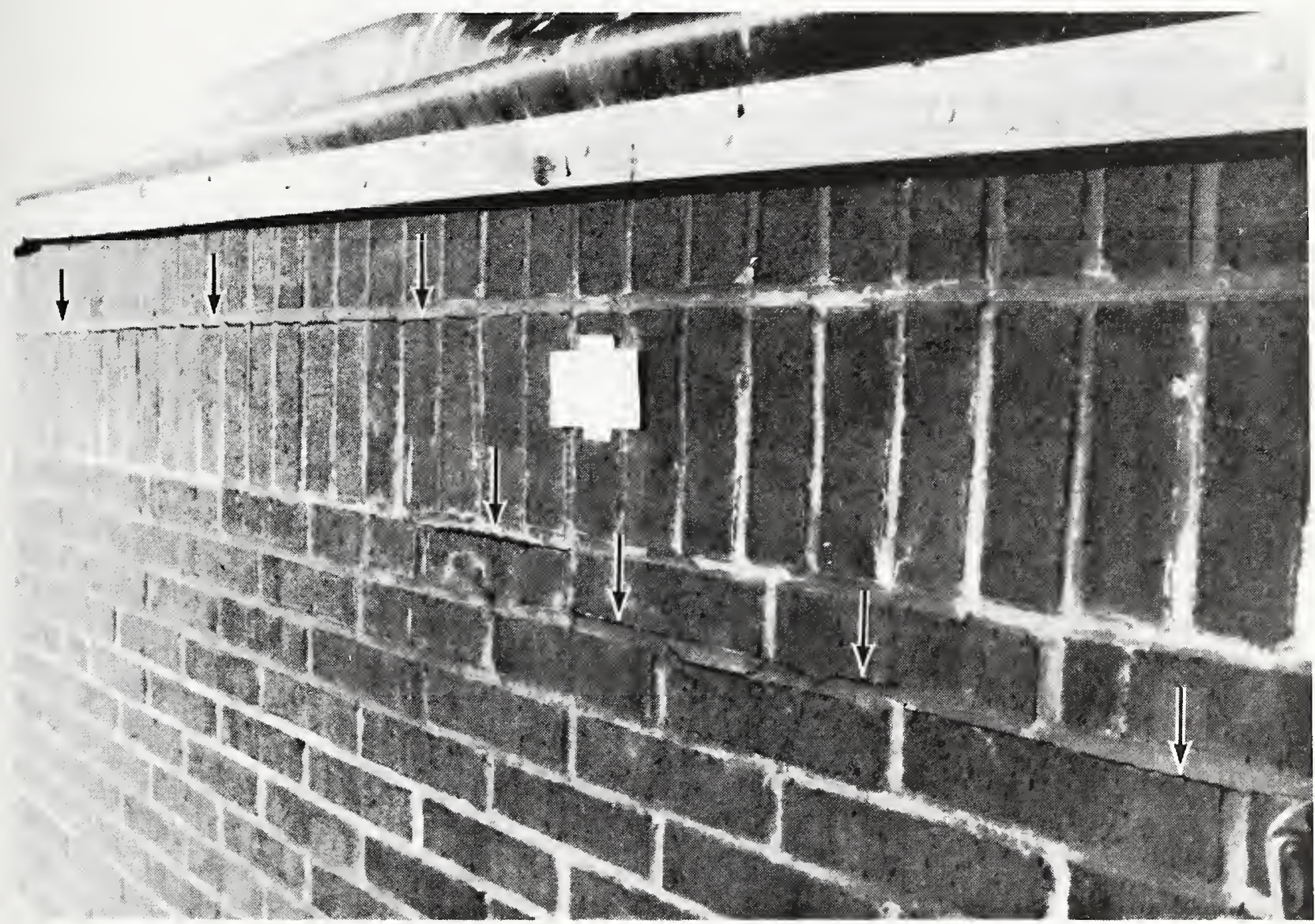

Figure 18 HORIZONTAL CRACKS IN SOUTH FACE OF PARAPET WALL 
